\title{
Dynamics of Land Use/Cover Change in Manikganj District, Bangladesh: A Case Study of Manikganj Sadar Upazila
}

\author{
Marju Ben Sayed, Shigeko Haruyama \\ Department of Environment Science and Technology, Mie University, Tsu, Japan \\ Email: 514d203@m.mie-u.ac.jp
}

Received 29 October 2015; accepted 1 December 2015; published 4 December 2015

Copyright (C) 2015 by authors and Scientific Research Publishing Inc.

This work is licensed under the Creative Commons Attribution International License (CC BY). http://creativecommons.org/licenses/by/4.0/

c) (i) Open Access

\section{Abstract}

This study revealed land use/cover change of Manikganj Sadar Upazila concerning with urbanization of Dhaka city. The study area also offers better residential opportunity and food support for Dhaka city. The major focus of this study is to find out the spatial and temporal changes of land use/cover and its effects on urbanization while Dhaka city is an independent variable. For analyzing land use/cover change GIS and remote sensing technique were used. The maps showed that, between 1989 and 2009 built-up areas increased approximately $+12 \%$, while agricultural land decreased $-7 \%$, water bodies decreased about $-2 \%$ and bare land decreased about $-2 \%$. The significant change in agriculture land use is observed in the south-eastern and north eastern site of the city because of nearest distance and better transportation facilities with Dhaka city. This study will contribute to the both the development of sustainable urban land use planning decisions and also for forecasting possible future changes in growth patterns.

\section{Keywords}

Land Use/Cover Change, Manikganj Sadar Upazila, Union, Urban Sprawl, Remote Sensing

\section{Introduction}

Like many other developing countries in the world, Bangladesh has experienced phenomenal growth of urban population in last four decades (14.1 million in 1981, 22.5 million 1991, 31.1 million in 2001, and 33.5 million in 2011) [1]. The large population of Bangladesh is squeezed into a small area 36,465,341 acre, yielding a mean density 4.2 persons/acre [1]. Rapid urbanization has led to the transformation of rural areas into urban areas, and it has been estimated that more than 199,908 acre (1\% of total agriculture land) of agricultural land is converted 
to cities, roads and infrastructure annually [2].

According to The Economist Intelligence Unit (EIU), Dhaka is the second worst livable city in the world. The population is growing by an estimated $4.2 \%$ per year, one of the highest rates amongst Asian cities [3]. Urban expansion of Dhaka was slow in the 1950s, but strong growth followed the independence of Bangladesh in 1971 [4]. Its growth has been particularly rapid since 1972, after its transformation from a provincial capital to the national capital of the structured zone of the city due to the accelerated rate of the urban growth in Dhaka [5].

Rural to urban migration remained the most dominant factor of population growth, but natural increase was also high [6]. The considerable growth observed in the population of Dhaka is thought to have occurred in response to large scale rural-urban migration, which has contributed, significantly to the increased rate of urbanization [7]. Dhaka supports more than 40\% of Bangladesh's industry, further suggesting that the some economic development and industrialization has led to a higher rate of urban expansion.

Manikganj Sadar Upazila has been emerged in the suburban area of Dhaka city. The study area offers developed transportation facility, better residential opportunity and food support for Dhaka city at the same time. Consequently it has become a place where people of different social backgrounds and strata are residing. In recent decades, rapid economic development such as: land reform, construction of roads, real estate development, industrial and commercial development has been accelerated the process of urbanization. This growth performing in an unplanned way and therefore, leads to a hazardous development.

There are only a few previous research works has been done on land use/cover change of the study area at the local and government level. Nahrin and Aktar (2007) in their article "Problems of Urban Utilities in the Secondary Towns of Bangladesh: A Case Study of Manikgonj Pourashava" which essential traces the utility coverage and present land use pattern of the study area [8]. Local Government Engineering Department (LGED, 2010) published "Manikganj Sadar Upazila map” and "Manikganj Sadar Upazila Road Network map” presented the current (2010) land use condition [9]. These reports and maps are not concerned with the temporal change of the socio-economic conditions of the study area. Realizing the situation this research has been conducted on Manikganj Sadar Upazila, where the major focus to clarify the urban sprawl of Dhaka city and land use change with socio-economic factors.

The objective of the study is to examine the spatial variations and temporal changes in various land use with remotely sensed data and to find out the land use change with social-economic background. Specifically, the purpose of the study is to analyze the temporal and spatial changes of agriculture land use in the study area concerning with urbanization of Dhaka city.

\section{Geographical Settings of the Study Area}

Manikganj district has been divided into seven Upazilas. Manikganj Sadar Upazila is bounded on the north by Saturia Upazila, on the east by Singair Upazila, on the south by Harirampur Upazila and on the west by Shivalaya Upazila and Ghior Upazila (Figure 1). The study area has a distance of $50 \mathrm{~km}$ from Dhaka city. The density of population is 4.5/acre. Total area of the study area is 53,080 acre. Manikganj Sadar Upazila has been divided into eleven Unions. Among all the unions Pourashova is the city center of Manikganj Sadar Upazila.

The heights and the lowest average monthly temperature vary from $35.1^{\circ} \mathrm{C}$ to $14.2^{\circ} \mathrm{C}$. The level of humidity varies from $56 \%$ to $83 \%$. The soil is mainly composed by the Young Active Brahmaputra flood plain representing silty and sandy alluvial soil. The Kaliganga River is the principal river that flow through the study area. In the study area, $43.43 \%$ of the dwelling households depend on agriculture as the main source of income with $27.49 \%$ cropping, livestock, forestry and fishery and $15.94 \%$ as agriculture labor [1]. The major agricultural crops are Rice, Jute, Wheat, Pulses, Oil seeds, Vegetables, Spices, Potato, Sweet potato. Among rice crops Boro covers the largest area followed by Aman and Aus.

\section{Materials and Methods}

The study was mainly based on collection and analysis of remote sensing data. The study also used both primary and secondary data were obtained from Bangladesh Population Census book (1981, 1991, 2001 and 2011), data and information relating to agriculture are obtained mainly from Bangladesh Agriculture Census (1984, 1996 and 2008) published by Bangladesh Bureau of Statistics (BBS).

The land use categories are classified as: agriculture land use, urban land use, water surface, bare land and vegetation cover. For GIS and remote sensing analysis, a time-series of Landsat Thematic Mapper (TM) and 
Enhanced Thematic Mapper Plus (ETM+) images were used to derive land use/cover maps of the study area were used (Figure 2). The images included the visible (bands 1, 2 and 3), the near infrared (NIR), the shortwave infrared (SWIR), and the middle infrared (MIR) bands with $30 \mathrm{~m}$ spatial resolution for TM and ETM+ images (Table 1). The dataset was mainly downloaded from the archive of Landsat (http://earthexplorer.usgs.gov). Af-

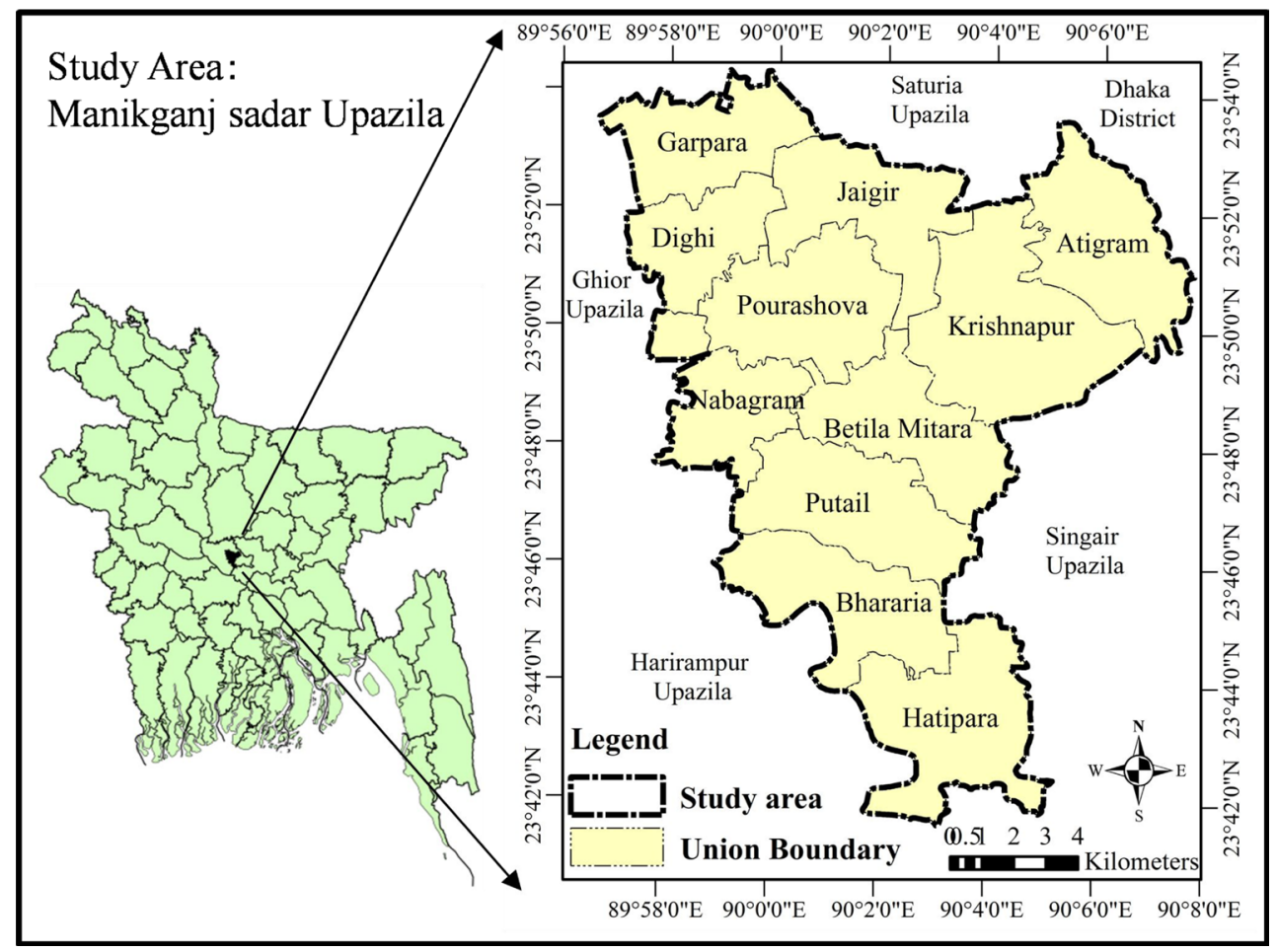

Figure 1. Location of the study area.

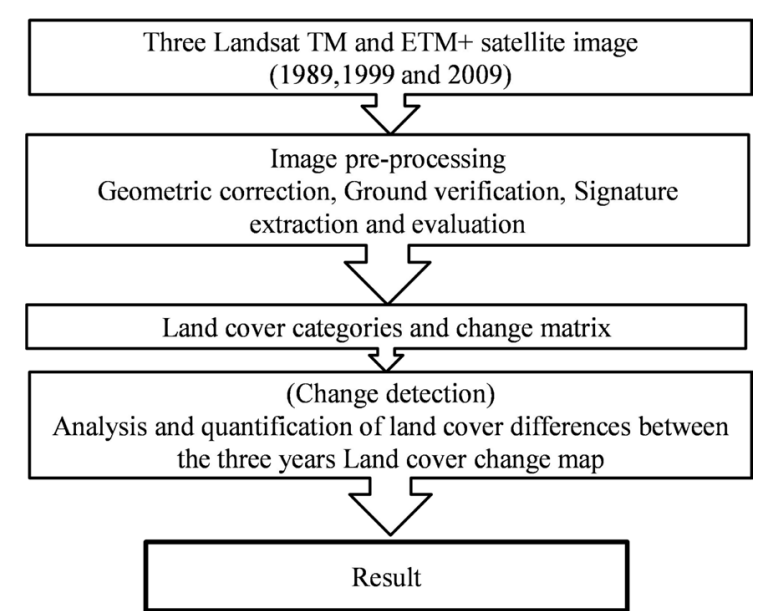

Figure 2. Methodology flow chart.

Table 1. Details of the landsat satellite images.

\begin{tabular}{cccc}
\hline Satellite name & Path and row & Date of acquisition & Special resolution \\
\hline Landsat-TM & 137 and 44 & 13th Feb., 1989 & 30 meters \\
Landsat-ETM+ & 137 and 44 & 24th Nov., 1999 & 30 meters \\
Landsat-TM & 137 and 44 & 26th Oct., 2009 & 30 meters \\
\hline
\end{tabular}


ter preprocessing the imageries, we performed supervised classification of both imageries with maximum likelihood classification algorithm in ERDAS IMAGINE 9.1 using the field data to produce five cover classes.

After classification in ERDAS, the classified imageries were exported to GIS for map production and generating land cover statistics. The image processing and analysis has been carried out using Arc Map 10 software. Field work was carried out during October 2014 for collecting ground training and validating data and for defining the characteristics of each land cover class.

\section{Result}

In 1989, agricultural land use amounted 35,242 acre (66\%) and decreased to 31,385 acre (59\%) in 2009 (Table 2), during the above mentioned 20 years, agriculture land use had decreased by161 acre in Atigram Union, 283 acre in Garpara Union, 966 acre in Hatipara Union, 231 acre in Jaigir Union, 353acre in Krishnapur Union, 596 acre in Bhararia union, 172 acre in Pourashova Union and 585 acre in Putail Union (Figure 3).

The decrease of agriculture land use was caused by development of infrastructure and factory (in Pourashova, Krishnapur, Atigarm area), saw mills (Pourashova area, Krishnapur and Jaigir area). From 1989 to 2009, a significant decrease of agriculture land use is found in Hatipara Union, Krishnapur union and Bhararia Union because of nearest distance from Dhaka city and transportation network development. The size of agricultural land mainly depends on the growth of the settlements, being an important factor influencing land-cover changes [10]. Usually, the major land-use change is caused by the increasing demand for non-agricultural land because of urban and manufacturing development [11].

The urban land use is composed of residential land use, commercial land use and industrial land use (Figure 3). The urban land use area was 10,057 acre (19\%) and expanded to 17,049 acre (31\%) in all unions (Figure 4). Theremark able change had occurred during 1999 to 2009. In 1999, urban land use amounted 12,491 acre (23\%) increased to 17,049 acre (31\%) in 2009. The notable changes are found in Hatipara Union (increased by 125 acre), Pourashova Union (increased by 688 acre) and Bhararia Union (increased by 962 acre). From 1989 to 2009, Urban land use had increased by 544 acre in Dighi Union, 437 acre in Garpara Union, 556 acre in Jaigir Union, 844 acre in Krishnapur Union, 309 acre in Nabagram Union and 540 acre in Putail Union. It is easy to convert agricultural infrastructure into urban infrastructure in the urban fringe of deltaic Asian cities [12]. Commercial and industrial land use changes have been observed also with the growth of the area.

The major land-use change is caused by the increasing demand for non-agricultural land because of urban and infrastructure development [13]. The commercial land use includes shops, banks, hotels, restaurants, government office, cinema hall have been established gradually in Pourashova Union, Krishnapur Union, Nabagram Union and Aitgram Union area. The majority of urban land was acquired by converting areas that were previously agricultural land, vegetation and water bodies [14].

Table 2. Data for land use/cover change from 1989 to 2009 of Manikganj Sadar Upazila by Union.

(Area in acre)

\begin{tabular}{cccccccccccccccccc}
\hline \multirow{2}{*}{ Union } & \multicolumn{4}{c}{ Agriculture land use } & \multicolumn{4}{c}{ Urban land use } & \multicolumn{4}{c}{ Water surface } & \multicolumn{3}{c}{ Bare land } & \multicolumn{3}{c}{ Vegetation cover } \\
\cline { 2 - 6 } & 1989 & 1999 & 2009 & 1989 & 1999 & 2009 & 1989 & 1999 & 2009 & 1989 & 1999 & 2009 & 1989 & 1999 & 2009 \\
\hline Atigram & 3812 & 3740 & 3651 & 734 & 977 & 1234 & 256 & 208 & 125 & 164 & 147 & 89 & 166 & 60 & 34 \\
Betila Mitara & 2911 & 2897 & 2760 & 555 & 667 & 933 & 372 & 331 & 241 & 308 & 290 & 278 & 79 & 42 & 14 \\
Bhararia & 2821 & 2601 & 2226 & 1174 & 1523 & 2136 & 272 & 241 & 137 & 262 & 211 & 107 & 143 & 96 & 68 \\
Dighi & 1836 & 1742 & 1513 & 526 & 668 & 1070 & 420 & 384 & 286 & 273 & 285 & 237 & 103 & 79 & 51 \\
Garpara & 2457 & 2483 & 2175 & 961 & 1075 & 1398 & 195 & 181 & 128 & 30 & 26 & 57 & 171 & 48 & 56 \\
Hatipara & 3986 & 3527 & 3021 & 1156 & 1673 & 2391 & 214 & 200 & 210 & 316 & 328 & 189 & 280 & 224 & 141 \\
Jaigir & 3201 & 3074 & 2970 & 984 & 1275 & 1540 & 298 & 214 & 98 & 190 & 148 & 139 & 109 & 72 & 36 \\
Krishnapur & 4976 & 4854 & 4623 & 1566 & 1882 & 2409 & 237 & 157 & 80 & 373 & 259 & 224 & 271 & 270 & 87 \\
Nabagram & 2571 & 2640 & 2536 & 573 & 594 & 881 & 231 & 203 & 94 & 174 & 137 & 102 & 122 & 95 & 56 \\
Pourashova & 2985 & 2988 & 2813 & 970 & 1241 & 1658 & 437 & 328 & 306 & 592 & 475 & 288 & 101 & 54 & 20 \\
Putail & 3685 & 3524 & 3100 & 858 & 917 & 1398 & 361 & 353 & 273 & 155 & 251 & 306 & 115 & 129 & 98 \\
Total & 35,242 & 34,070 & 31,385 & 10,057 & 12,491 & 17,049 & 3293 & 2799 & 1976 & 2836 & 2558 & 2016 & 1660 & 1169 & 661 \\
\hline
\end{tabular}



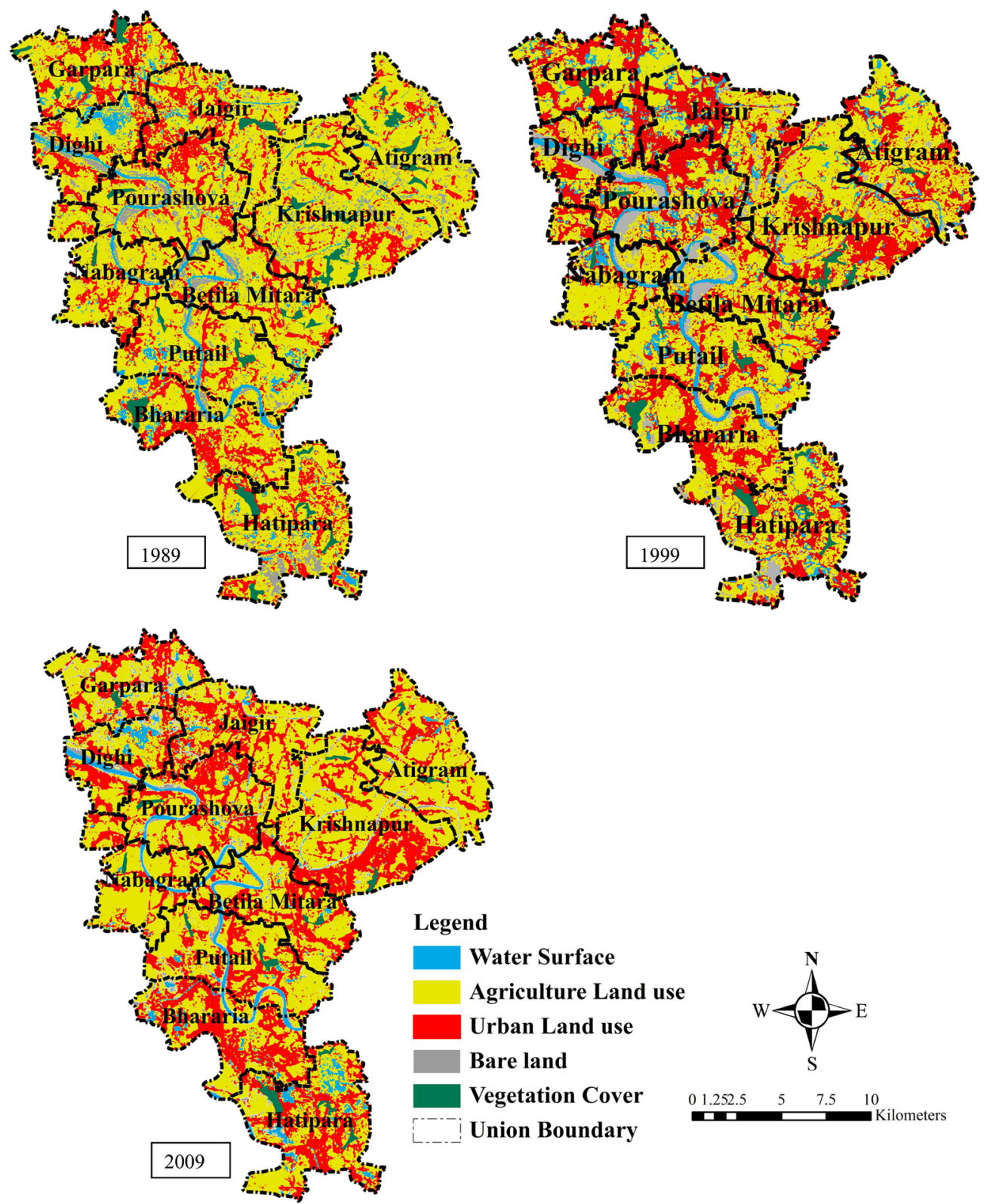

Figure 3. Temporal variations in land use/cover of Manikganj Sadar Upazila during 1989-2009.

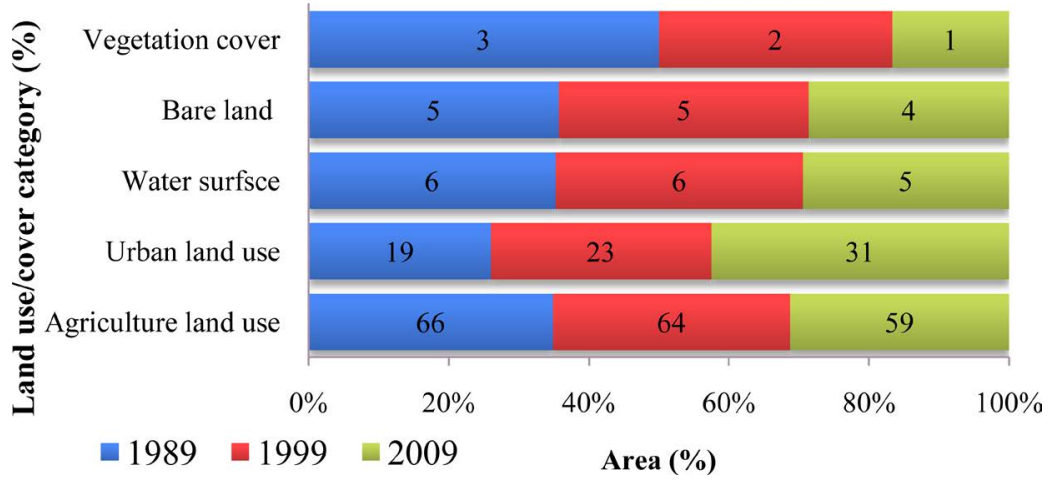

Figure 4. Dynamics of land use/cover change in Manikganj Sadar Upazila. 
In 1989, bare land amounted 2836 acre (5\%) and decreased to 2016 acre (4\%) in 2009 (Table 3). During the above mentioned 20 years, the bare land had decreased by 304 acre in Pourashova Union, 126 acre in Hatipara Union, 75 acre in Atigram Union and 72 acre in Nabagram Union. The net bare land area had decreased because with the increase of population, the demand of food had increased too. As a result, the bare has been converted to both agriculture land use and urban land use. In opposite, the bare land had increased by 150 acre in Putail Union, and 28 acre in Garpara Union (Table 3).

The water surface was 3293 acre (6\%) in 1989 and dropped to 1976 acre (5\%) in 2009 (Table 2). The decrease of water surface was a result of the construction of residential, commercial and industrial zone to promote urban development (Figure 5). Water surface had decreased by 131 acre in Atigram Union, 132 acre by Betila

Table 3. Data for land use/cover change from 1989 to 2009 of Manikganj Sadar Upazila.

\begin{tabular}{|c|c|c|c|c|c|c|c|c|c|c|c|c|}
\hline SL No. & Land use category & $\begin{array}{c}1989 \\
\text { (in acre) }\end{array}$ & $\%$ & $\begin{array}{c}1999 \\
\text { (in acre) }\end{array}$ & $\%$ & $\begin{array}{c}2009 \\
\text { (in acre) }\end{array}$ & $\%$ & $\begin{array}{c}\text { From } \\
1989 \text { to } 1999\end{array}$ & $\%$ & $\begin{array}{c}\text { From } \\
1999 \text { to } 2009\end{array}$ & $\%$ & Class change to \\
\hline 1 & Agriculture land use & 35,242 & 66 & 34,070 & 64 & 31,385 & 59 & -1172 & -2 & -2685 & -5 & Urban land use \\
\hline 2 & Urban land use & 10,057 & 19 & 12,491 & 23 & 17,049 & 31 & 2435 & 4 & 4557 & 8 & Bare land \\
\hline 3 & Water surface & 3293 & 6 & 2799 & 6 & 1976 & 5 & -493 & -1 & -823 & -1 & Agriculture land use \\
\hline 4 & Bare land & 2836 & 5 & 2558 & 5 & 2016 & 4 & -278 & -1 & -542 & -1 & $\begin{array}{l}\text { Urban land use, } \\
\text { agriculture land use }\end{array}$ \\
\hline \multirow[t]{2}{*}{5} & Vegetation cover & 1660 & 3 & 1169 & 2 & 661 & 1 & -491 & -1 & -508 & -1 & Urban land use \\
\hline & Total & 53,088 & 100 & 53,088 & 100 & 53,088 & 100 & & & & & \\
\hline
\end{tabular}

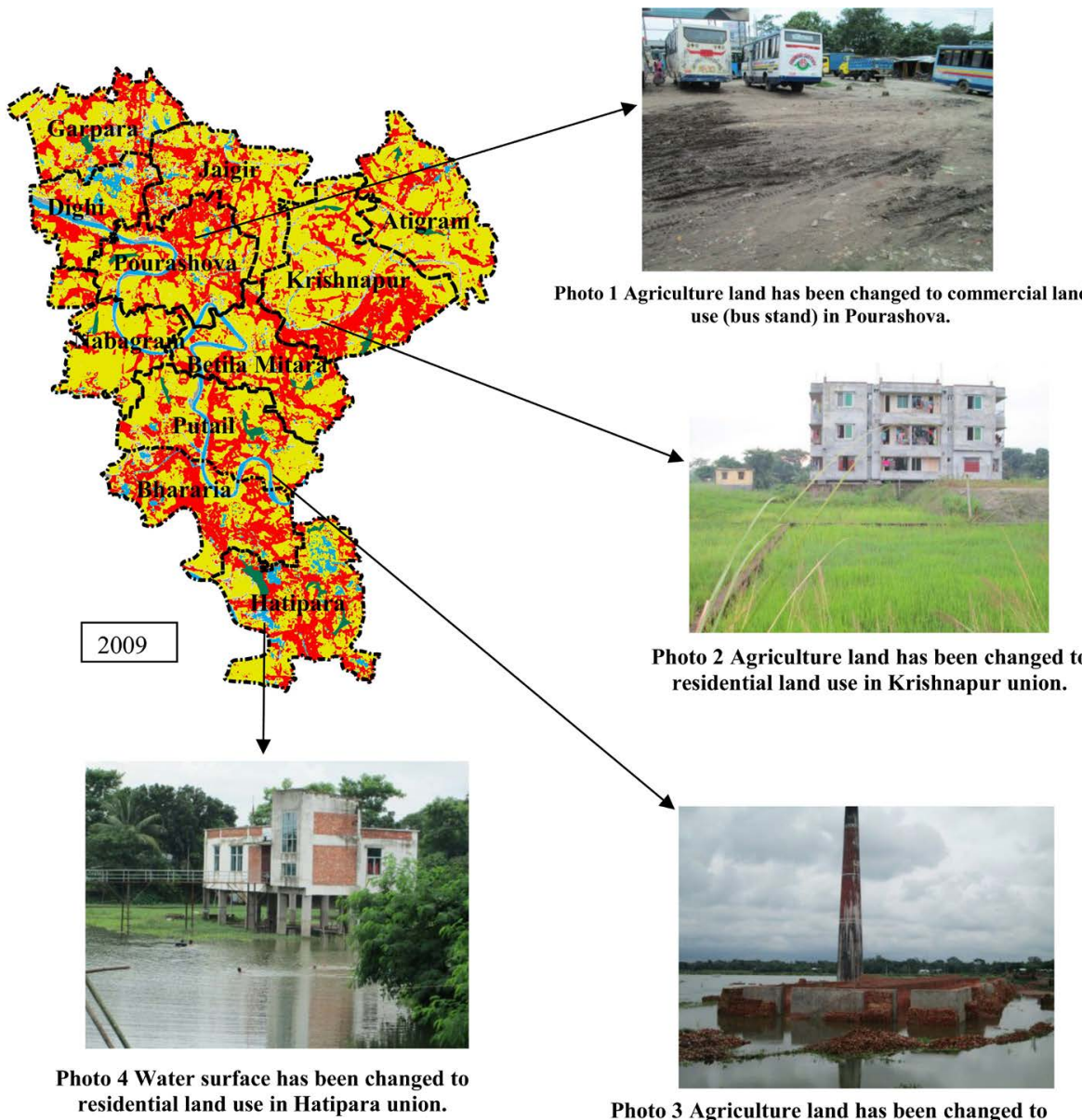

industrial land use (brick field) in Putail union.

Figure 5. Land use/cover changing pattern in different union of Manikganj Sadar Upazila. 
Mitara Union, 136 acre in Bhararia Union, 134 acre in Dighi Union, 200 acre Jaigir Union, 157acre in Krishnapur Union, 137 acre in Nabagram Union and 131 acre in Pourashova Union.

The vegetation cover was 1660 acre (3\%) in 1989 and dropped to 661 acre (1\%) in 2009 (Table 2). The decrease of vegetation cover was a result of the construction of residential, commercial and industrial zone to promote urban development. Vegetation cover had decreased by 133 acre in Atigram Union, 65 acre by BetilaMitara Union, 76 acre in Bhararia Union, 51 acre in Dighi Union, 72 acre Jaigir Union, 185 acre in Krishnapur Union, 65 acre in Nabagram Union and 81 acre in Pourashova Union (Table 3).

Census data indicate that, Manikganj Sadar Upazila had a total population of 209,855 in 1981. The population increased steadly 237,771 in 1991, but it markedly increased from 261,662 in 2001 to 309,413 in 2011. With the expansion of total population, the percentage of male female population had changed too. In 1981, male 50.24\% and female $49.76 \%$, in next thirty years the male female population percentage had changed, male $48.29 \%$ and female $51.71 \%$ in 2011. During the period from 1981 to 2011, the number of urban population of the study area had increased by 37,132 in 1981 to 71,698 in 2011. The accelerated industrialization and urbanization following economic reforms and population increases have greatly affected land-use change through the increase of built-u areas and urban sprawl [15]. Urban expansion is positively related to population growth [12]. The relationship between urban growth and increasing population was inspected and found strong correlation (Table 4).

In 1984, farm household was $67.07 \%$ of total household area and it became $59.27 \%$ in 1996 . According to the agriculture census (2008), farm household has been decreased to 50.99\% (Figure 6). From 1996 to 2008, during recent 12 years, the reduction rate is higher because of urbanization greatly contributed to the loss of agriculture land. In opposite in 1984, small farm household was 13,941 (74.01\%) of total household and 19,370 (85.81\%) in 1996. In 2008, small farm household has been increased to 28,996 (90.21\%). From 1996 to 2008, during recent 12 years, on-farm holdings has been increased by 1100 in Betila Mitara Union, 500 in Bhararia Union, 300 in Dighi Union, 800 in Hatipara Union, 700 in Jaigir Union, 1100 in Krishnapur Union, 200 in Nabagram Union, and 700 in Putail Union. The correlation between urban expansion and percentage of non-farm holdings also examined and revealed very strong association (Table 4).

According to the population census (1991), 92.12\% population had engaged with agriculture activity (as a main source of income). In the next ten years, from 1991 to 2000 the growth rate was normal. However, the population engage with agricultural activity had dropped in 2011 with $28.34 \%$. Such a great variation within ten

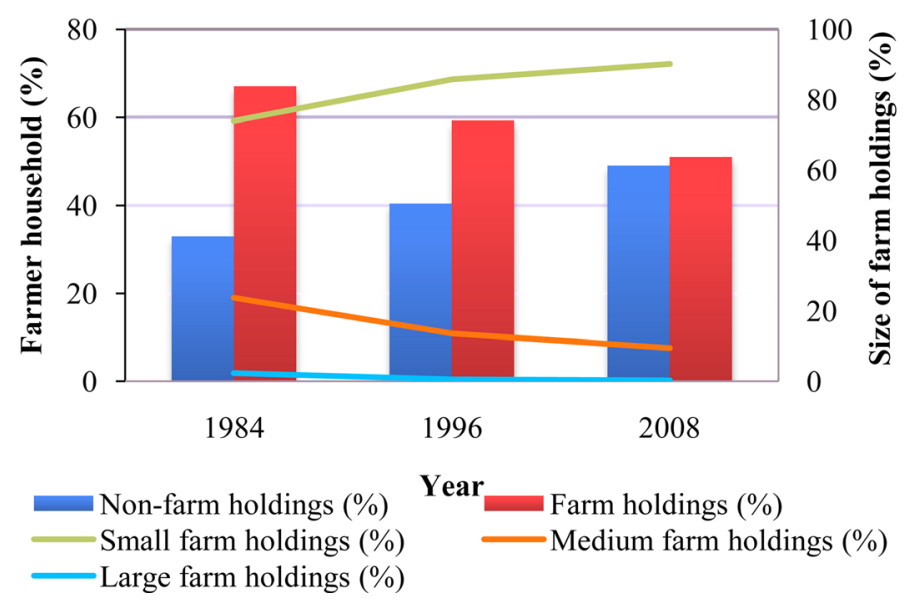

Figure 6. Relationship between farmer household and size of farm holdings.

Table 4. Pearson correlation coefficients between socio-economic variables and urban growth.

\begin{tabular}{ccccc}
\hline Socio-economic and demographic variable & 1991 & 2001 & 2011 & 309,413 \\
Total population & 237,771 & 261,662 & 50.99 & -0.99 \\
Farm holdings (\%) & 67.07 & 59.27 & 90.21 & 0.94 \\
Small size farm holdings (\%) & 74.01 & 85.81 & 90.94 \\
\hline
\end{tabular}

Source: Population census, 2011. 
years was attributed to the education policy development. With the development of education policy compare to agricultural activity the demand of service sector has been increased. The social economic factors play the most important decision role in deciding the range of cultivated land change [16]. Employment is an important factor influencing landscape changes [10]. During the period from 2001 to 2011, population involving rate with service sector was high $24.91 \%$.

\section{Conclusions}

This study evaluated the temporal and spatial changes of land use in the study area comparing with urbanization of Dhaka city. In the study area urban land use has been increased by 4\% during 1989 to 1999 and $8 \%$ from 1999 to 2009, which resulted in a significant decrease in the area of agriculture land use, water surface, bare land and vegetation cover. In the study area, the growing population and faster economic activities has been increased. But in opposite, the amount of agricultural land has reduced substantially, largely as a result of the increasing demand of land for urban land uses. The significant change in agriculture land use has been observed in Pourashova and also in the south-eastern and north-eastern site of the study area because of nearest distance and better transportation network with Dhaka city.

In the study area during the above mentioned 20 years, a significant urban land use expansion has been largely driven by population growth and economic activity. Comparatively the growth rate and the number of population of the study area are much greater than all other Upazilas on account of locational advantage linking Dhaka city.

Urban land use expansion should be restrained on agriculture land use, vegetation cover and water surface. Agriculture land must be prohibited from any kind of development activity. Agriculture land use must be preserved for food support for both Dhaka city and Manikganj Sadar Upazila. Existing natural canals, ponds and other water surface should be kept for ecological balance. Moreover, regional and local land use management policy should be needed to be revised for proper land use management. The land use/cover maps produced in this study will contribute to both the forecasting possible future changes in growth patterns and also for the development of sustainable urban land use planning decisions.

\section{References}

[1] Bangladesh Bureau of Statistics (BBS) (1991, 2001, 2011) Population Census 1991, 2001, 2011. Ministry of Planning, Dhaka.

[2] Bangladesh Bureau of Statistics (BBS) (1996, 1999) Agricultural Census of Bangladesh 2008. Ministry of Planning, Dhaka.

[3] McGee, T. (2001) Urbanization Takes on New Dimensions in Asia’s Population Giants, Population Reference Bureau. http://www.prb.org/pdf/PT_Oct2001.pdf

[4] Chowdhury, A.M. and Faruqui, S. (1989) Physical Growth of Dhaka City. In: Ahmed, S.U., Ed., Dhaka: Past, Present and Future, The Asiatic Society of Bangladesh, Dhaka, 43-61.

[5] Asaduzzaman, M. and Rob, A.M. (1997) Environmental Controls over Urbanization of Dhaka City. The Mappa, Dhaka.

[6] Rasheed, K.B.S. (2008) Bangladesh Resource and Environmental Profile. A H Development Publishing House, Dhaka.

[7] Islam, N. (1996) Dhaka from City to Megacity: Perspectives on People, Places, Planning and Development Issues. Urban Studies Program, Department of Geography, University of Dhaka, Dhaka.

[8] Nahrin, K. and Aktar, M. (2007) Problems of Urban Utilities in the Secondary Towns of Bangladesh: A Case Study of Manikgonj Pourashava. Jahangirnagar University: Department of Urban and Regional Planning. Jahangirnagar Planning Review, 5, 75-84.

[9] Local Government Engineering Department (LGED) (2010) Digital Map Download, English. http://www.lged.gov.bd/ViewMap.aspx

[10] Wang, Y. and Zhang, X. (2001) A Dynamic Modeling Approach to Simulating Socio Economic Effects on Landscape Changes. Ecological Modelling, 140, 141-162. http://dx.doi.org/10.1016/S0304-3800(01)00262-9

[11] Verburg, P.H., Veldkamp, A. and Fresco, L.O. (1999) Simulation of Changes in the Spatial Pattern of Land Use in China. Applied Geography, 19, 211-233. http://dx.doi.org/10.1016/S0143-6228(99)00003-X

[12] Hara, Y., Takeuchi, K. and Okubo, S. (2005) Urbanization Linked with Past Agricultural Land Use Patterns in the Ur- 
ban Fringe of a Deltaic Asian Mega-City: A Case Study in Bangkok. Landscape and Urban Planning, 73, 16-28. http://dx.doi.org/10.1016/j.landurbplan.2004.07.002

[13] World Bank (1992) Indonesia: Agricultural Transformation Challenges and Opportunities. Report No. 1054-IND, Washington.

http://www-wds.worldbank.org/external/default/WDSContentServer/WDSP/IB/1992/09/01/000009265 39610022055 15/Rendered/PDF/multi_page.pdf

[14] Dewan, A.M. and Yamaguchi, Y. (2009) Land Use and Land Cover Change in Greater Dhaka, Bangladesh: Using Remote Sensing to Promote Sustainable Urbanization. Applied Geography, 29, 390-401. http://dx.doi.org/10.1016/j.apgeog.2008.12.005

[15] Wu, L.X., Sun, B., Zhou, S.L., Huang, S.E. and Zhao, Q.G. (2004) A New Fusion Technique of Remote Sensing Images for Land Use/Cover. Pedosphere, 14, 187-194.

[16] Deng, X., Huang, J., Rozelle, S., Zhang, J. and Li, Z. (2015) Impact of Urbanization on Cultivated Land Changes in China. Land Use Policy, 45, 1-7. http://dx.doi.org/10.1016/j.landusepol.2015.01.007

\section{Notes}

Upazila: Upazila is the sub-units of districts. The Upazilas are the second lowest tier of regional administration in Bangladesh. Manikganj district has been divided into seven upazilas.

Union: Union is the smallest rural administrative and local government unit in Bangladesh. Manikganj Sadar Upazila has been divided into eleven unions. 